\title{
Green synthesis of silver nanoparticles using Cadaba indica lam leaf extract and its larvicidal and pupicidal activity against Anopheles stephensi and Culex quinquefasciatus
}

\author{
K. Kalimuthu, ${ }^{1,2}$ C. Panneerselvam, ${ }^{1}$ K. Murugan, ${ }^{1}$ J.-S. Hwang ${ }^{2}$ \\ ${ }^{1}$ Division of Entomology, Department of Zoology, School of Life Sciences, Bharathiar University, \\ Coimbatore, India; ${ }^{2}$ Institute of Marine Biology, National Taiwan Ocean University, Taiwan
}

\begin{abstract}
Green nanoparticle synthesis was achieved using environmentally acceptable plant extracts and eco-friendly reducing and capping agents. In the present study, activity of silver nanoparticles (AgNPs) synthesized using Cadaba indica lam plant against Anopheles stephen$s i$ and Culex quinquefasciatus was determined. A range of concentrations of synthesized AgNPs (3.125, 6.25, 12.5, 25, $50 \mathrm{ppm})$ and crude extract (50,100, 150, 200, $250 \mathrm{ppm})$ were tested against $A$. stephensi and $C$. quinquefasciatus. The synthesized AgNPs from $C$. indica lam were much more toxic than crude extract in both mosquito species. The cured extract high mortality values were $50 \%$ lethal concentration $\left(\mathrm{LC}_{50}\right)=88.22,90.84 \mathrm{ppm} ; 90 \%$ lethal concentration $\left(\mathrm{LC}_{90}\right)=172.94$, $178.55 \mathrm{ppm}$, and the AgNPs high mortality values were $\mathrm{LC}_{50}=3.90,4.39$ ppm; $\mathrm{LC}_{90}=19.04,17.35 \mathrm{ppm}$ against $A$. stephensi and $C$. quinquefasciatus, respectively. The results recorded from ultraviolet-visible spectrophotometer, scanning electron microscopy, energy dispersive X-ray and Fourier transformed infrared support the biosynthesis and characterization of silver nanoparticles. These results suggest that the leaf
\end{abstract}

Correspondence: Kandasamy Kalimuthu, Division of Entomology, Department of Zoology, School of Life Sciences, Bharathiar University, Coimbatore - 641 046, India. Tel.: +91.770.875.5603.

E-mail: biokalimuthu@yahoo.in

Key words: Cadaba indica lam, silver nanoparticles, Anopheles stephensn, Culex quinquefasciatus.

Acknowledgments: the authors are grateful to Dr. K. Sasikala, Professor and Head, Department of Zoology, Bharathiar University for the laboratory facilities providing for this experiment.

Received for publication: 12 December 2012.

Revision received: 31 May 2013.

Accepted for publication: 7 June 2013.

(C) Copyright K. Kalimuthu et al., 2013

Licensee PAGEPress, Italy

Journal of Entomological and Acarological Research 2013; 45:e11

doi:10.4081/jear.2013.e11

This article is distributed under the terms of the Creative Commons Attribution Noncommercial License (by-nc 3.0) which permits any noncommercial use, distribution, and reproduction in any medium, provided the original author(s) and source are credited. cured extracts of $C$. indica lam and green synthesis of silver nanoparticles have the potential to be used as an ideal eco-friendly approach for the control of $A$. stephensi and $C$. quinquefasciatus.

\section{Introduction}

Vector-borne diseases transmitted by blood-feeding mosquitoes, such as dengue hemorrhagic fever, Japanese encephalitis, malaria, and filariasis, are increasing in prevalence worldwide, particularly in tropical and subtropical zones. Malaria now is responsible for illness in more than an estimated 300 million people, resulting in one million deaths per year (WHO, 2007). Culex quinquefasciatus is a vector of lymphatic filariasis, which affects 120 million people worldwide, and approximately 400 million people are at risk of contracting filariasis, resulting in an annual economic loss of 1.5 billion dollars (WHO, 2002). Lymphatic filariasis is a serious public health problem in India, constituting one third of the infected population in the world (WHO et al., 1997). Mosquito-borne diseases are endemic to India due to favorable ecological conditions for the vectors, their close contact with humans, and their reproductive biology. In rubber plantations, the rich organic content, stagnant water, low light levels and protected conditions in the coconut shells used in rubber production favors intense breeding (Sumodan, 2003). Mosquito control is improving in many areas, but there are significant challenges, including increasing resistance to insecticides and a lack of alternative, cost-effective, and safe insecticides. This increase in insecticide resistance requires the development of strategies for prolonging the use of highly effective vector control compounds. The use of combinations of multiple insecticides and phytochemicals is one such strategy that may be suitable for mosquito control. Attempts to develop novel materials as mosquito larvicides are still necessary. With the progress of nanotechnology research, many laboratories around the world have investigated silver nanoparticles (AgNPs) production.

The development of green processes for the synthesis of nanoparticales is evolving into an important brach of nanotechnology. Nanoparticles play an indispensable role in drug delivery, diagnostics, imaging, sensing, gene delivery, artificial implants, and tissue engineering (Morones \& Elechigerra, 2005). The development of a reliable green process for the synthesis of silver nanoparticles is an important aspect of current nanotechnology research. Biological methods for nanoparticle synthesis using microorganisms, enzymes, and plants or plant extracts have been suggested as possible eco-friendly alternatives to chemical and physical methods (Mohanpuria et al., 2008). Recently, green silver nanoparticles have been synthesized using various natural products such as Nelumbo nucifera (Santhoshkumar et 
al., 2011), Pongamia pinnata (Rajesh et al., 2010), Azadirachta indica (Tripathi et al., 2009), Glycine max (Vivekanandhan et al., 2009), Cinnamon zeylanicum (Sathishkumar et al., 2009), and Camellia sinensis (Begum et al., 2009). In recent studies, potential mosquito larvicidal activity of synthesized AgNPs from plant extracts as well as physical methods is well documented (Marimuthu et al., 2011; Thirunavukkarasu et al., 2010; Sap-Iam et al., 2010).

Plants are rich sources of bioactive organic chemicals and offer an advantage over synthetic pesticides, as these are less toxic, less prone to development of resistance, and easily biodegradable. India can utilize its rich supply of herbs for such purposes, as plant extracts are not only potentially insecticides, but also can act as effective antimicrobial, antifungal, anti- parasitic and anti-malarial agents. Plant materials not only offer effective mosquito control agents, but also promise to be environmentally safer. Therefore, an alternative approach for mosquito control is the use of natural products of plant origin. The botanical insecticides are generally pest-specific, readily biodegradable, and usually lack toxicity to higher animals (Bowers, 1992). In traditional medicine systems, different parts of the plant have been described to be useful against a variety of diseases. The leaves of Cadaba indica lam plant are rich in lactones, steroids, flavonoids, alkaloids, reducing sugars and tannins (Peach \& Tracy 1955; Rastogi \& Mehrotra, 1991). $C$. indica lam leaf extract is used on boils; its leaf juice is used as eye drops. Against cattle fever, a decoction of fresh leaves, pepper and garlic is administered orally (Reddy et al., 2007). However, the activity of the ethanol extract of the leaves was found to be most effective against bacteria and fungi (Selvamani \& Latha, 2005). The leaf and flower liquid extract mixed with castor oil and turmeric is taken as a remedy for menorrhagia, syphilis, and as a purgative (Alagesaboopathi, 2009). Pathak et al. (2000) reported that the steam-distilled whole plant oil extract of Tagetes minuta gave 100\% mortality against larvae of Anopheles stephensi, Culex quinquefasciatus and Aedes aegypti at doses lower than $100 \mathrm{ppm}$. Volatile oil extracted from the peel of citrus fruits has also shown toxic effects on mosquito larvae as well as adults (Ezeonu et al., 2001).

In the present study, we report on the synthesis of silver nanoparticles, reducing the silver ions present in the solution of silver nitrate by $C$. indica lam leaf extract, and its efficacy against $A$. stephensi and $C$. quinquefasciatus.

\section{2}

\section{Materials and methods}

\section{Materials}

The Cadaba indica lam plants were collected in and around Kaveri river bank, Namakkal District, in Tamilnadu, India, and identified by the taxonomist, Department of Botany, Bharathiar University, Coimbatore, India. The voucher specimen was numbered and kept in the authors' research laboratory for further reference. Silver nitrate $\left(\mathrm{AgNO}_{3}\right)$ was purchased from Precision Scientific Co., Coimbatore, India.

\section{Mosquito rearing}

The eggs of $A$. stephensi and $C$. quinquefasciatus were collected from the National Centre for Disease Control field station of Mettupalayam, Tamil Nadu, India. These were brought to the laboratory and transferred (in approximately the same aliquot numbers of eggs) into $18 \mathrm{~cm}$ $\mathrm{L} \times 13 \mathrm{~cm} \mathrm{W \times 4} \mathrm{cm} \mathrm{D}$ enamel trays containing $500 \mathrm{~mL}$ of water, where they were allowed to hatch. Mosquito larvae were reared (and adult mosquitoes held) at $27 \pm 2^{\circ} \mathrm{C}$ and $75-85 \%$ relative humidity in a $14: 10$ (L/D) photoperiod. The larvae were fed 5-g ground dog biscuit and brewer's yeast daily in a 3:1 ratio. The pupae were collected and trans- ferred into plastic containers with $500 \mathrm{~mL}$ of water. The container was placed inside a screened cage $(90 \mathrm{~cm} \mathrm{~L} \times 90 \mathrm{~cm} \mathrm{H} \times 90 \mathrm{~W})$ to retain emerging adults, for which $10 \%$ sucrose in water solution (v/v) was made available. On day 5 post-emergence, the mosquitoes were provided access to a rabbit host for blood feeding. The shaved dorsal side of the rabbit was positioned on the top of the mosquito cage in contact with the cage screen (using a cloth sling to hold the rabbit) and held in this position overnight. Glass Petri dishes lined with filter paper and containing $50 \mathrm{~mL}$ of water were subsequently placed inside the cage for oviposition by female mosquitoes.

\section{Synthesis of silver nanoparticles}

Leaves were washed with distilled water and dried for 2 days at room temperature. A plant leaf broth was prepared by placing $10 \mathrm{~g}$ of the leaves (finely cut) in a $300-\mathrm{mL}$ flask with $100 \mathrm{~mL}$ of sterile distilled water. This mixture was boiled for $5 \mathrm{~min}$, decanted, stored at $-4^{\circ} \mathrm{C}$, and used in our tests within 1 week. The filtrate was treated with aqueous $1 \mathrm{mM} \mathrm{AgNO}{ }_{3}$ solution in an Erlenmeyer flask and incubated at room temperature. As a result, in a brown-yellow solution indicating the formation of AgNPs, it was found that aqueous silver ions can be reduced by aqueous extract of the plant parts to generate extremely stable silver nanoparticles in water.

\section{Characterization of silver nanoparticles}

The presence of synthesized silver nanoparticles was confirmed by sampling the reaction mixture at regular intervals and the absorption maxima was scanned by ultraviolet-visible (UV-vis) spectra at the wavelengths of $350-600 \mathrm{~nm}$ in a UV-3600 Shimadzu spectrophotometer at $1 \mathrm{~nm}$ resolution. Further, the reaction mixture was subjected to centrifugation at 15,000 rpm for $20 \mathrm{~min}$; the resulting pellet was dissolved in deionized water and filtered through a millipore filter $(0.45 \mu \mathrm{m})$. An aliquot of this filtrate containing silver nanoparticles was used for scanning electron microscopy (SEM) and energy dispersive X-ray (EDX) studies. Thin films of the sample were prepared on a carboncoated copper grid by dropping a small amount of the sample on the grid; extra solution was removed using a blotting paper, and the films on the SEM grid were allowed to dry by placing it under a mercury lamp for $5 \mathrm{~min}$. The surface groups of the nanoparticles were qualitatively confirmed by using Fourier transformed infrared spectroscopy (FTIR) (Stuart, 2002), with spectra recorded by a Perkin-Elmer Spectrum 2000 FTIR spectrophotometer.

\section{Larval/pupal toxicity test}

Twenty-five larvae (instars I-IV) or pupae were placed in $249 \mathrm{~mL}$ of dechlorinated water in a $500-\mathrm{mL}$ glass beaker, and $1 \mathrm{~mL}$ of the desired concentration of silver nanoparticles was added; $0.5 \mathrm{mg}$ of larval food was provided for each test concentration. Tests of each concentration against each instar and the pupae were replicated three times. In each case, the control comprised 25 larvae or pupae in $250 \mathrm{~mL}$ of distilled water. Control mortality was corrected by using Abbott's formula (Abbott, 1925), and percent mortality was calculated as follows:

$$
\text { Percent mortality }=\frac{\text { Number of dead larvae/pupae }}{\text { Number of larvae/pupae introduced }} \times 100
$$

\section{Statistical analysis}

Average larval mortality data were subjected to probit analysis for calculating $50 \%$ and $90 \%$ lethal concentration $\left(\mathrm{LC}_{50}\right.$ and $\mathrm{LC}_{90}$ ) values, using the method of Finney (1971). SPSS software, ver. 9.0 (StataCorp., College Station, TX, USA), was used. Results were considered to be statistically significant at $\mathrm{P}<0.05$. 


\section{Results and discussion}

Several approaches have been employed to obtain better biosynthesis of nanoparticles, which is preferable to chemical and physical methods, as it is a cost-effective and environmentally friendly method, and does not require the use of high pressure, energy, temperature, or toxic chemicals (Sinha et al., 2009; Goodsell, 2004). In the present study, the larvicidal and pupicidal effects of ethanol leaf extracts and synthesized AgNPs of $C$. indica lam were noted; the highest mortality was found in synthesized AgNps against larvae and pupae of $A$. stephensi $\left(\mathrm{LC}_{50}=3.90\right.$, 4.67, 10.20, 15.41, $25.27 \mathrm{ppm}$ and $\mathrm{LC}_{90}=19.04,27.06,47.72,61.07,78.32$ $\mathrm{mg} / \mathrm{L})$ and $C$. quinquefasciatus $\left(\mathrm{LC}_{50}=4.39,5.07,8.21,15.44,23.83 \mathrm{mg} / \mathrm{L}\right.$ and $\mathrm{LC}_{90}=17.35,20,35.76,58.37,75.33 \mathrm{ppm}$ ), respectively (Table 1 and Figure 1). The highest mortality was found against the larvae and pupae of $A$. stephensi $\left(\mathrm{LC}_{50}=88.22,107.34,136.98,169.04,270.68 \mathrm{mg} / \mathrm{L}\right.$ and $\mathrm{LC}_{90}=172.94,209.09,284.08,314.46,474.85 \mathrm{ppm}$ ) and $C$. quinquefasciatus $\left(\mathrm{LC}_{50}=90.84,115.37,145.18,172.92,288.86 \mathrm{mg} / \mathrm{L}\right.$ and $\mathrm{LC}_{90}=178.55,211.37,277.29,311.29,525.13 \mathrm{ppm}$ ), respectively (Table 2 and Figure 2). Chi-square values were significant at the $\mathrm{P} \leq 0.05$ level. Fifty-percent hydroethanolic extracts of Bonninghausenia albiflora whole plant, Calotropis procera root, Citrus maxima flower, Acorus calamus rhizome, and Weidelia chinensis whole plant showed acaricidal efficacy ranging from $4 \%$ to $35 \%$ within $24 \mathrm{~h}$ of application on
Rhipicephalus (Boophilus) microplus. Rhizome extract of A. calamus revealed that a $79.31 \%$ correlation with $\log$ concentration in probit mortality could be assigned to the concentration of the extract, and the regression line of the extract showed the $\mathrm{LC}_{85}$ as $11.26 \%$ (Ghosh et al., 2011). Chandran et al. (2006) synthesized silver nanoparticles by using Aloe vera extract at $24 \mathrm{~h}$ of incubation. Previous authors reported that the methanol extract of Cassia fistula exhibited $\mathrm{LC}_{50}$ values of 17.97 and $20.57 \mathrm{mg} / \mathrm{L}$ for A. stephensi and C. quinquefasciatus, respectively (Govindarajan et al., 2008). A 23\% mortality was noted against firstinstar larvae of $A$. stephensi by treatment of $A$. ilicifolius extract at 20 ppm; this increased to $89 \%$ at 100 ppm (Kovendan \& Murugan, 2011). Mosquitocidal properties of Calotropis gigantea leaf extract and bacterial insecticidal properties of Bacillus thuringiensis against these mosquito vectors have been reported by Kovendan et al. (2012).

Reduction of silver ions in the aqueous solution during reaction with the ingredients present in plant leaf extract was observed by UV-visible spectroscopy. The color change was noted by visual observation in the $C$. indica lam leaf extracts when incubated with $\mathrm{AgNO}_{3}$ solution. $C$. indica lam leaf extract without $\mathrm{AgNO}_{3}$ did not show any change in color (Figure 3). The color of the extract changed to light brown within an hour, and later changed to dark brown during a $1 \mathrm{~h}$ incubation period, after which no significant change occurred. Appearance of the yellowish brown color was an indication of formation of colloidal silver nanoparticles in the medium. The brown color could be due to the exci-

Table 1. Larvicidal activity of $C$. indica lam crude leaf ethnolic extract against larva and pupa of $A$. stephensi and $C$. quinquefasciatus.

\begin{tabular}{|c|c|c|c|c|c|c|c|c|c|c|c|}
\hline Species & $\begin{array}{c}\text { Life } \\
\text { stages } \\
\text { (instars) }\end{array}$ & $\begin{array}{l}\text { Perc } \\
50\end{array}$ & $\begin{array}{l}\text { entage of } \\
\text { Concentr } \\
100\end{array}$ & $\begin{array}{c}\text { arval and } \\
\text { ition of } E \\
150\end{array}$ & $\begin{array}{c}\text { pupal mo } \\
\text { C (ppm) } \\
200\end{array}$ & $\begin{array}{l}\text { rtality } \\
250\end{array}$ & Slope & $\mathrm{LC}_{50}\left(\mathrm{LC}_{90}\right)$ & $\begin{array}{c}95 \% \text { confic } \\
\text { LCL } \\
\text { LC }_{50}\left(\mathrm{LC}_{90}\right)\end{array}$ & $\begin{array}{l}\text { UCL limit } \\
\text { LC }_{50}\left(\mathrm{LC}_{90}\right)\end{array}$ & $\begin{array}{c}X^{2} \\
(\mathrm{df}=3)\end{array}$ \\
\hline A. stephensi & $\begin{array}{l}\text { I } \\
\text { II } \\
\text { III } \\
\text { IV } \\
\text { Pupa }\end{array}$ & $\begin{array}{c}30.0 \pm 2.4 \\
25.6 \pm 3.6 \\
21.2 \pm 3.3 \\
13.8 \pm 2.2 \\
8.0 \pm 1.0\end{array}$ & $\begin{array}{l}56.2 \pm 2.3 \\
42.2 \pm 2.4 \\
33.8 \pm 3.0 \\
24.2 \pm 3.6 \\
15.2 \pm 3.4\end{array}$ & $\begin{array}{l}80.0 \pm 2.0 \\
71.8 \pm 2.6 \\
62.8 \pm 2.2 \\
49.6 \pm 2.8 \\
22.8 \pm 2.0\end{array}$ & $\begin{array}{l}95.8 \pm 2.2 \\
88.4 \pm 3.0 \\
70.4 \pm 2.2 \\
61.6 \pm 3.8 \\
30.2 \pm 3.0\end{array}$ & $\begin{array}{l}100 \pm 1.2 \\
96.2 \pm 1.0 \\
81.2 \pm 1.6 \\
73.4 \pm 1.2 \\
46.4 \pm 2.8\end{array}$ & $\begin{array}{l}0.359 \\
0.374 \\
0.313 \\
0.313 \\
0.183\end{array}$ & $\begin{array}{c}88.22(172.94) \\
107.34(209.09) \\
136.98(284.08) \\
169.04(314.46) \\
270.68(474.85)\end{array}$ & $\begin{array}{c}77.06(160.36) \\
95.61(194.30) \\
122.60(258.08) \\
155.65(285.28) \\
241.07(402.53)\end{array}$ & $\begin{array}{c}97.89(189.33) \\
117.80(228.84) \\
150.50(321.54) \\
183.56(356.63) \\
320.08(605.86)\end{array}$ & $\begin{array}{l}1.383 \\
1.051 \\
3.890 \\
2.571 \\
0.522\end{array}$ \\
\hline C. quinquefasciatus & $\begin{array}{l}\text { I } \\
\text { II } \\
\text { III } \\
\text { IV } \\
\text { Pupa }\end{array}$ & $\begin{array}{c}28.2 \pm 2.2 \\
21.0 \pm 2.4 \\
16.8 \pm 3.0 \\
11.8 \pm 2.8 \\
8.8 \pm 2.1\end{array}$ & $\begin{array}{l}54.8 \pm 2.0 \\
40.8 \pm 2.2 \\
30.2 \pm 2.8 \\
22.6 \pm 3.4 \\
15.4 \pm 2.2\end{array}$ & $\begin{array}{l}81.2 \pm 2.0 \\
66.4 \pm 1.6 \\
58.6 \pm 2.2 \\
45.2 \pm 2.8 \\
24.6 \pm 3.2\end{array}$ & $\begin{array}{l}92.6 \pm 2.2 \\
85.6 \pm 2.8 \\
70.0 \pm 3.0 \\
64.6 \pm 2.2 \\
31.4 \pm 3.2\end{array}$ & $\begin{array}{c}100 \pm 1.0 \\
97.8 \pm 1.2 \\
82.40 \pm 1.4 \\
71.8 \pm 1.0 \\
40.6 \pm 2.6\end{array}$ & $\begin{array}{l}0.362 \\
0.396 \\
0.342 \\
0.324 \\
0.159\end{array}$ & $\begin{array}{c}90.84(178.55) \\
115.37(211.37) \\
145.18(277.29) \\
172.92(311.29) \\
288.86(525.13)\end{array}$ & $\begin{array}{c}79.50(165.69) \\
104.70(197.44) \\
132.51(254.27) \\
160.05(283.70) \\
251.76(432.37)\end{array}$ & $\begin{array}{l}100.69(195.26) \\
125.20(230.68) \\
157.58(309.39) \\
187.01(350.82) \\
357.53(709.61)\end{array}$ & $\begin{array}{l}1.731 \\
1.107 \\
2.607 \\
2.921 \\
0.387\end{array}$ \\
\hline
\end{tabular}

$\mathrm{LC}_{50}, 50 \%$ lethal concentration; $\mathrm{LC}_{90}, 90 \%$ lethal concentration; $\mathrm{EEC}$, ethanolic extract of Cadaba indica lam; Control nil mortality; LCL, lower confidence limit; UCL, upper confidence limit; df, degrees of freedom. Each value is the mean $\pm \mathrm{SD}$ of five replicates.

Table 2. Larvicidal activity of synthesized silver nanoparticles using $C$. indica lam leaf extract against larvae and pupa of $A$. stephensi and C. quinquefasciatus.

\begin{tabular}{|c|c|c|c|c|c|c|c|c|c|c|c|}
\hline Species & $\begin{array}{c}\text { Life } \\
\text { stages } \\
\text { (instars) }\end{array}$ & $\begin{array}{r}\text { Perc } \\
3.125\end{array}$ & $\begin{array}{c}\text { entage of } \\
\text { Concent } \\
6.25\end{array}$ & $\begin{array}{c}\text { rval and } \\
\text { ion of A } \\
12.5\end{array}$ & $\begin{array}{l}\text { Ipal m } \\
\text { Ps (pp } \\
25\end{array}$ & $\begin{array}{l}\text { ality } \\
50\end{array}$ & Slope & $\mathrm{LC}_{50}\left(\mathrm{LC}_{90}\right)$ & $\begin{array}{c}95 \% \text { con } \\
\text { LCL } \\
\text { LC }_{50}\left(\mathrm{LC}_{90}\right)\end{array}$ & $\begin{array}{l}\text { nce limit } \\
\text { UCL } \\
\text { LC }_{50}\left(L C_{90}\right)\end{array}$ & $\begin{array}{c}X^{2} \\
(\mathrm{df}=3)\end{array}$ \\
\hline A. stephensi & $\begin{array}{c}\text { I } \\
\text { II } \\
\text { III } \\
\text { IV } \\
\text { Pupa }\end{array}$ & $\begin{array}{l}42.0 \pm 2.8 \\
40.8 \pm 2.4 \\
35.2 \pm 2.0 \\
29.8 \pm 3.4 \\
21.8 \pm 3.6\end{array}$ & $\begin{array}{l}61.2 \pm 3.0 \\
55.6 \pm 3.8 \\
42.6 \pm 3.5 \\
40.0 \pm 2.6 \\
33.4 \pm 2.8\end{array}$ & $\begin{array}{l}80.8 \pm 1.0 \\
71.4 \pm 2.4 \\
58.2 \pm 2.5 \\
51.2 \pm 2.2 \\
42.6 \pm 2.6\end{array}$ & $\begin{array}{l}94.6 \pm 1.1 \\
88.4 \pm 1.4 \\
75.0 \pm 1.8 \\
66.4 \pm 2.4 \\
55.8 \pm 2.6\end{array}$ & $\begin{array}{l}100 \pm 1.2 \\
98.8 \pm 1.0 \\
88.4 \pm 1.4 \\
80.2 \pm 1.0 \\
68.8 \pm 1.3\end{array}$ & $\begin{array}{l}1.068 \\
1.128 \\
1.099 \\
1.010 \\
0.918\end{array}$ & $\begin{array}{c}3.90(19.04) \\
4.67(27.06) \\
10.20(47.72) \\
15.41(61.07) \\
25.27(78.32)\end{array}$ & $\begin{array}{c}1.42(16.48) \\
1.43(23.32) \\
6.04(40.95) \\
10.97(51.50) \\
13.80(53.53)\end{array}$ & $\begin{array}{c}5.72(23.00) \\
7.13(32.80) \\
13.68(58.18) \\
19.51(76.74) \\
45.48(190.03)\end{array}$ & $\begin{array}{l}3.378 \\
3.376 \\
4.909 \\
4.895 \\
6.095\end{array}$ \\
\hline C. quinquefasciatus & $\begin{array}{cc}S \quad \text { I } \\
\text { II } \\
\text { III } \\
\text { IV } \\
\text { Pupa }\end{array}$ & $\begin{array}{l}44.2 \pm 3.0 \\
40.0 \pm 2.4 \\
36.8 \pm 1.6 \\
30.4 \pm 3.4 \\
27.2 \pm 3.0\end{array}$ & $\begin{array}{l}53.2 \pm 2.4 \\
55.2 \pm 2.1 \\
43.2 \pm 2.0 \\
36.4 \pm 2.0 \\
30.4 \pm 2.4\end{array}$ & $\begin{array}{l}85.8 \pm 1.0 \\
77.8 \pm 2.1 \\
63.4 \pm 2.7 \\
51.6 \pm 3.5 \\
42.6 \pm 3.3\end{array}$ & $\begin{array}{l}96.2 \pm 1.0 \\
94.2 \pm 1.0 \\
82.4 \pm 2.0 \\
68.4 \pm 1.8 \\
56.4 \pm 2.7\end{array}$ & $\begin{array}{l}100 \pm 1.0 \\
100 \pm 1.0 \\
95.4 \pm 1.4 \\
81.2 \pm 1.2 \\
71.4 \pm 1.0\end{array}$ & $\begin{array}{l}1.099 \\
1.158 \\
1.227 \\
1.063 \\
0.942\end{array}$ & $\begin{array}{c}4.39(17.35) \\
5.07(20.00) \\
8.21(35.76) \\
15.44(58.37) \\
23.83(75.33)\end{array}$ & $\begin{array}{c}2.37(15.12) \\
2.89(17.40) \\
4.99(31.11) \\
3.93(42.23) \\
19.26(62.54)\end{array}$ & $\begin{array}{c}5.93(20.74) \\
6.76(23.96) \\
10.92(42.62) \\
25.07(110.23) \\
29.18(97.33)\end{array}$ & $\begin{array}{l}5.051 \\
1.843 \\
4.851 \\
5.801 \\
2.888\end{array}$ \\
\hline
\end{tabular}

$\mathrm{LC}_{50}, 50 \%$ lethal concentration; $\mathrm{LC}_{90}, 90 \%$ lethal concentration; AgNPs, silver nanoparticles; Control nil mortality; LCL, lower confidence limit; UCL, upper confidence limit; df, degrees of freedom. Each value is the mean \pm SD of five replicates. 


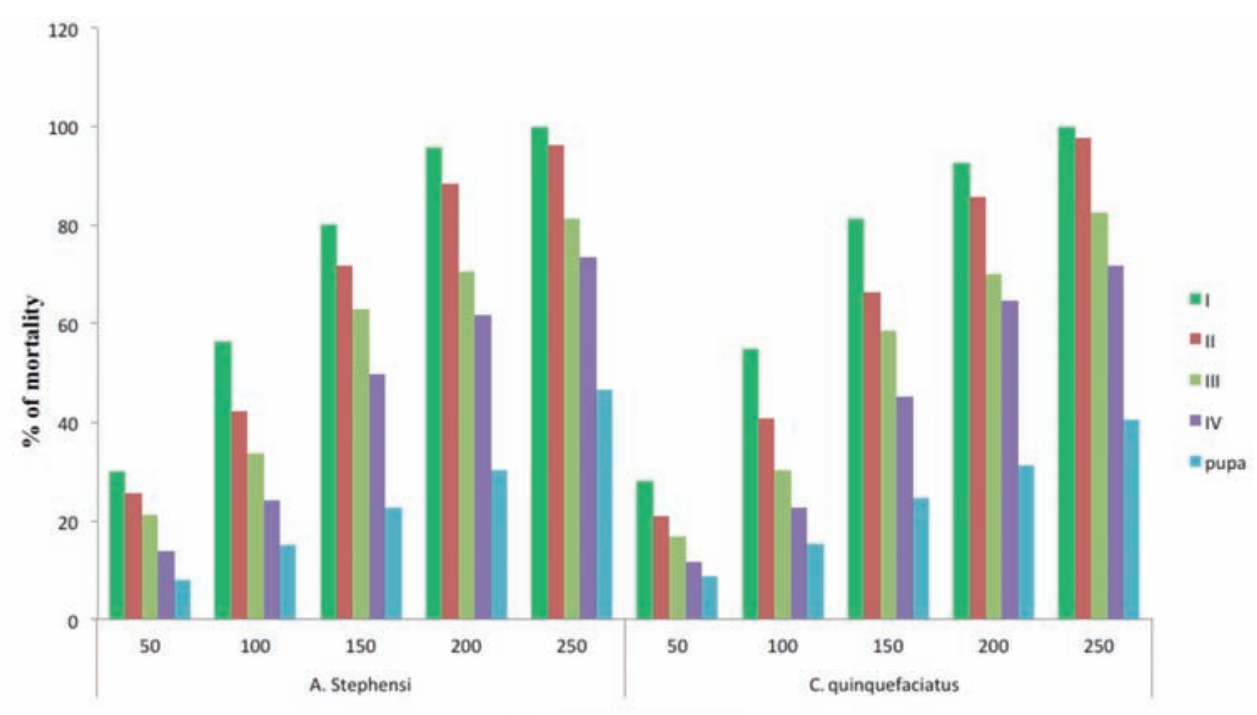

Concentration (ppm)
Figure 1. Larvicidal activity of $C$. indica lam crude leaf ethnolic extract against larva and pupa of A. stephensi and C. quinquefasciatus.

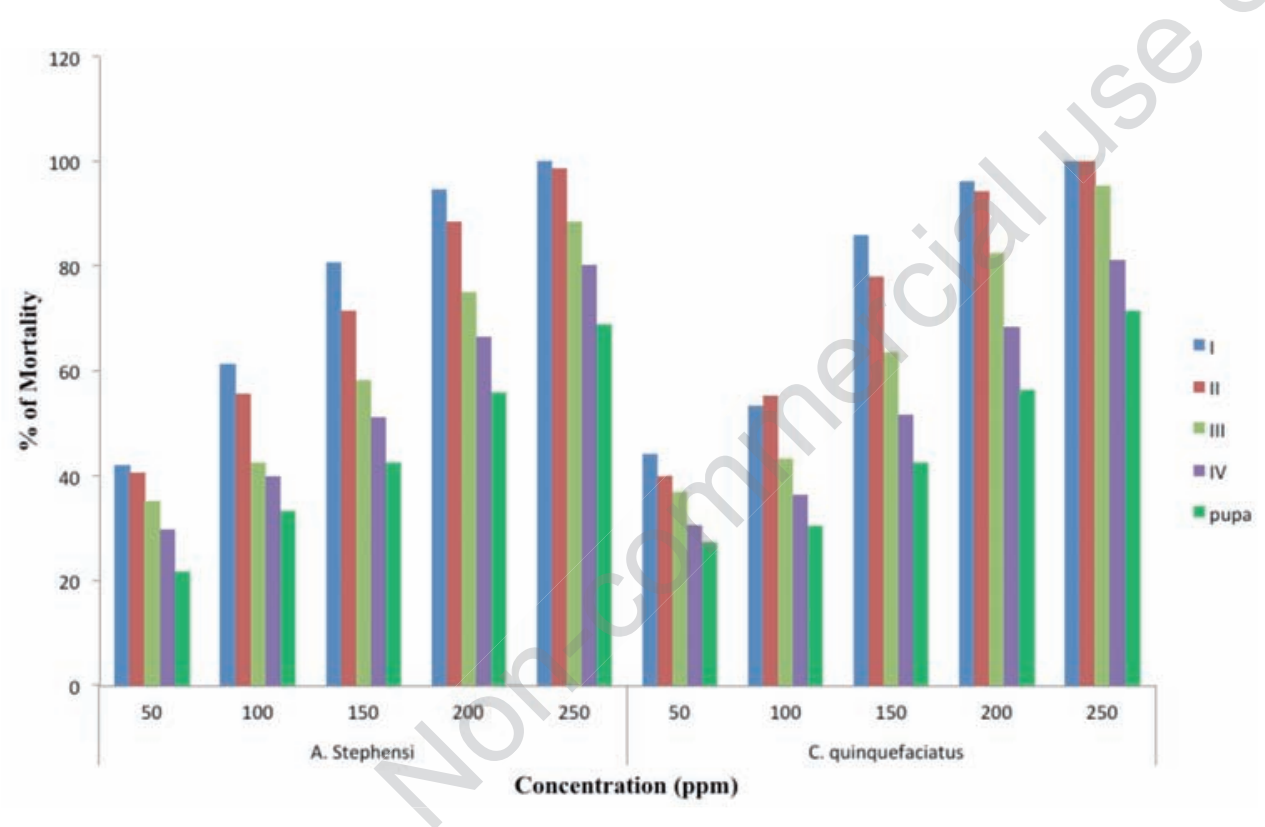

Figure 2. Larvicidal activity of synthesized silver nanoparticles using C. indica lam leaf extract against larvae and pupa of $A$. stephensi and $C$. quinquefasciatus.

tation of surface plasmon vibrations, typical of silver nanoparticles (Ahmad et al., 2003; Krishnaraj et al., 2010). The dark brown color of the silver colloid is attributable to surface plasmon resonance arising from the group of free conduction electrons induced by an interacting electromagnetic field (Song \& Kim, 2008). The strong surface plasmon resonance band appears at the range of $420-480 \mathrm{~nm}$ and the broadening peak indicates that the particles are monodispersed (Figure 4). These color changes arise because of the excitation of surface plasmon vibrations in the silver nanoparticles (Mulvaney, 1996).

SEM (JEOL-MODEL 6390) image showing high density Ag nanoparticles synthesized by $C$. indica lam plant extracts further confirmed the presence of Ag nanoparticles (Figure 5). It was shown that relatively spherical and uniform Ag nanoparticles were formed with a diameter of $30-60 \mathrm{~nm}$. The SEM image of silver nanoparticles synthesized by plant extracts were assembled on the surface due to interactions such as hydrogen bonding and electrostatic interactions between the bioorganic capping molecules bound to the Ag nanoparticles. It was found that relatively spherical and uniform silver nanoparticles were formed. The nanoparticles were not in direct contact, even within the aggregates, indicating stabilization of the nanoparticles by a capping agent (Song \& Kim, 2008). Silver nanoparticles have been characterized using SEM by various investigators (Durán et al., 2005; Balaji et al., 2009). Silver nanoparticles were synthesized using leaf extracts of Acalypha indica; from the SEM image, the size of the control silver nitrate obtained was more than $1000 \mathrm{~nm}$, whereas synthesized silver nanoparticles measured 20-30 nm in size (Krishnaraj et al., 2010). Tian et al. (2007) reported that numerous flavonoids, including quercetin or quercetin 3-0-glycosides, were isolated from lotus leaves that were used for silver nanoparticle synthesis. The element analysis of the silver nanoparticles was performed using EDX on the SEM. Figure 6 
shows the EDX spectrum of AgNPs synthesized at $25^{\circ} \mathrm{C}$ and $80^{\circ} \mathrm{C}$; strong signals from the silver atoms in the nanoparticles were observed, and signals from calcium, potassium, oxygen, sodium, magnesium, sulphur, Ag and chloro were also recorded. The results indicate that the reaction product was composed of higher level Ag nanoparticles.

The AgNPs produced by $C$. indica lam leaf extract were distinct and scattered in distribution. The Fourier transformed infrared spectra of AgNPs exhibited prominent peaks at $3453 ; 3288 ; 1790 ; 1638 ; 1384$; 1114; 1077; 371; $360 \mathrm{~cm}^{-1}$ (Figure 7). The sharp absorption peak at $1638 \mathrm{~cm}^{-1}$ was assigned to $\mathrm{C}=0$ stretching vibration in the carbonyl compounds, which may be characterized by the presence of a high content of terpenoids and flavonoids. The peaks at $1077 \mathrm{~cm}^{-1}$ correspond to $\mathrm{C}-\mathrm{N}$ stretching vibration of aliphatic amines or alcohols/phenols, representing the presence of polyphenols. The absorption bands at $1088 \mathrm{~cm}^{-1}$ in the fingerprint region indicate several modes such as $\mathrm{C}-\mathrm{H}$ deformation or $\mathrm{C}-\mathrm{O}$ or $\mathrm{C}-\mathrm{C}$ stretching, pertaining to carbohydrates. The bands at 1383 to $1431 \mathrm{~cm}^{-1}$ were assigned to scissoring

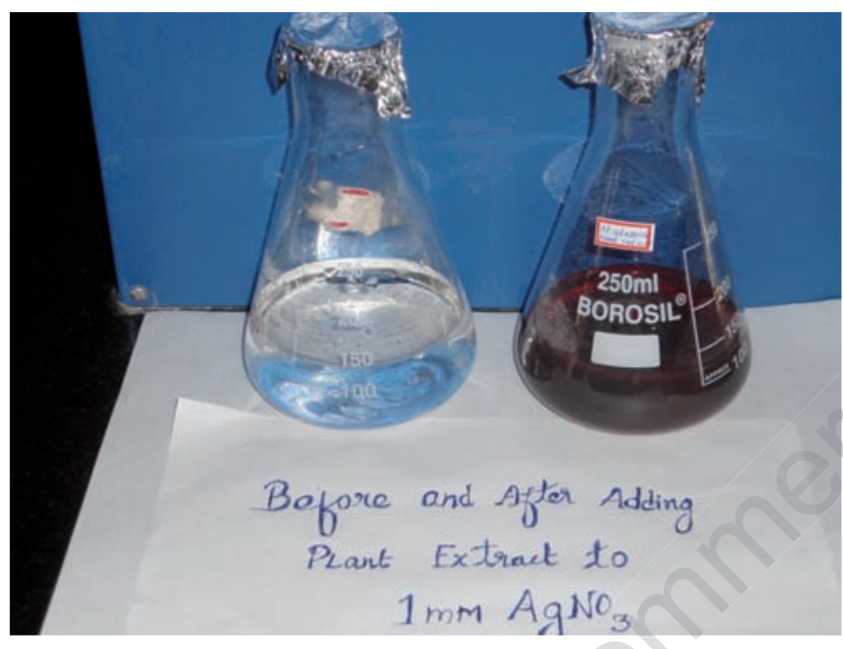

Figure 3. Photographs showing change in color after adding silver nitrate $\left(\mathrm{AgNO}_{3}\right)$ before reaction and after reaction time of $30 \mathrm{~min}$.

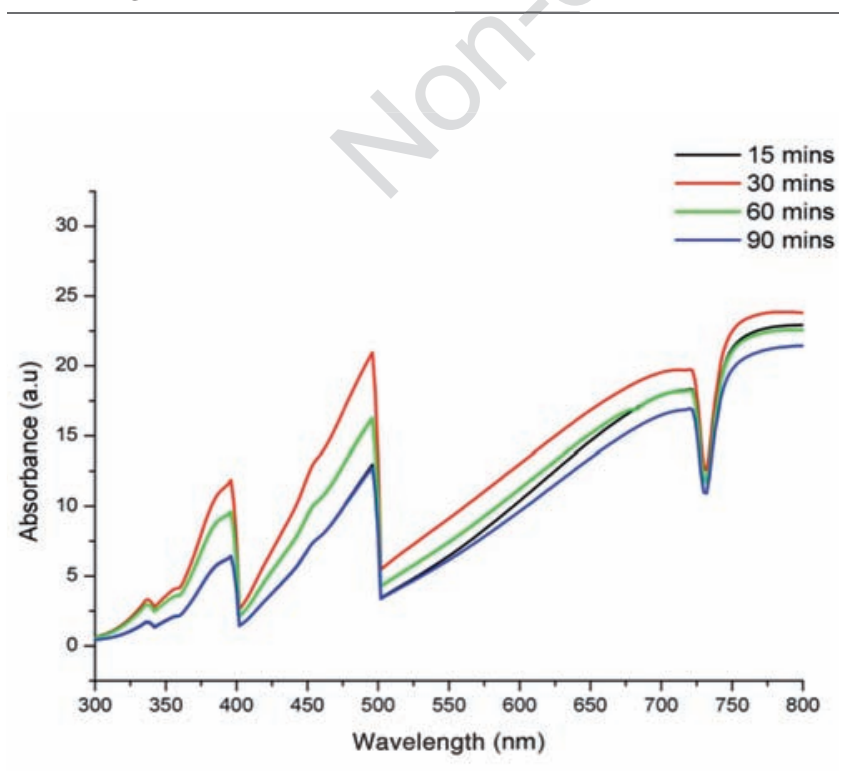

Figure 4. Ultraviolet-visible spectra of aqueous silver nitrate with C. indica lam leaf extract at different time intervals. modes of methylene tails, CH3 R. A broad intense band at $3402 \mathrm{~cm}^{-1}$ in both the spectra can be assigned to the $\mathrm{N}-\mathrm{H}$ stretching frequency arising from the peptide linkages present in the proteins of the extract (Mukherjee et al., 2008).

\section{Conclusions}

The present study of green synthesis shows that the environmentally benign and renewable source of $C$. indica lam is used as an effective reducing agent for the synthesis of AgNPs. This biological reduction of silver nanoparticles would be a boon for the development of a clean, nontoxic, and environmentally acceptable green approach to production of AgNPs, involving organisms extending even to higher plants. The AgNPs did not exhibit any noticeable effects on $C$. indica lam exposure at their $\mathrm{LC}_{50}$ and $\mathrm{LC}_{90}$ values against larvae of $A$. stephensi and $C$.
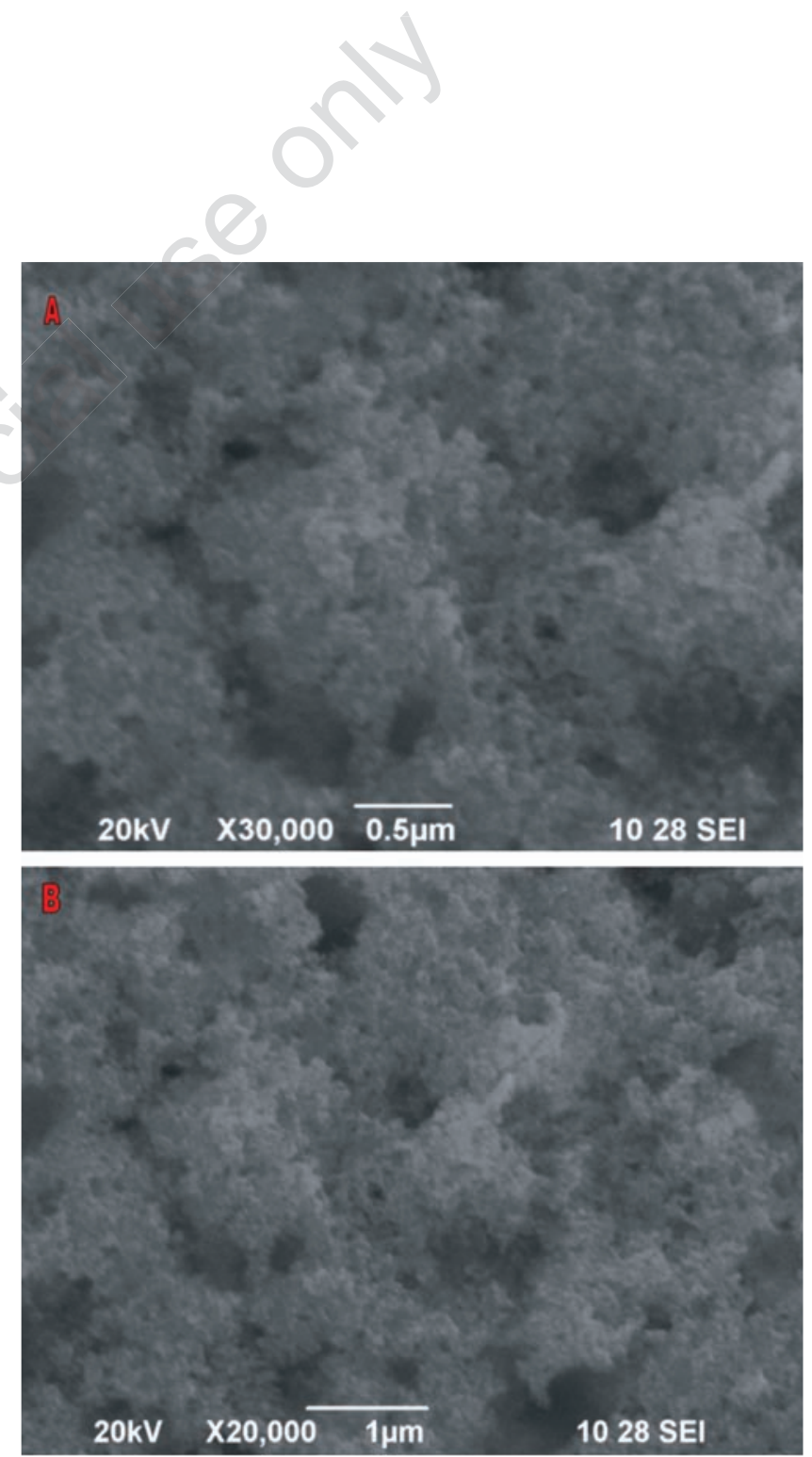

Figure 5. Image of scanning electron microscopic observation of synthesized silver nanoparticles. A) Lower magnification $(0.5$ $\mu \mathrm{m})$; B) Higher magnification (1 $\mu \mathrm{m})$. 


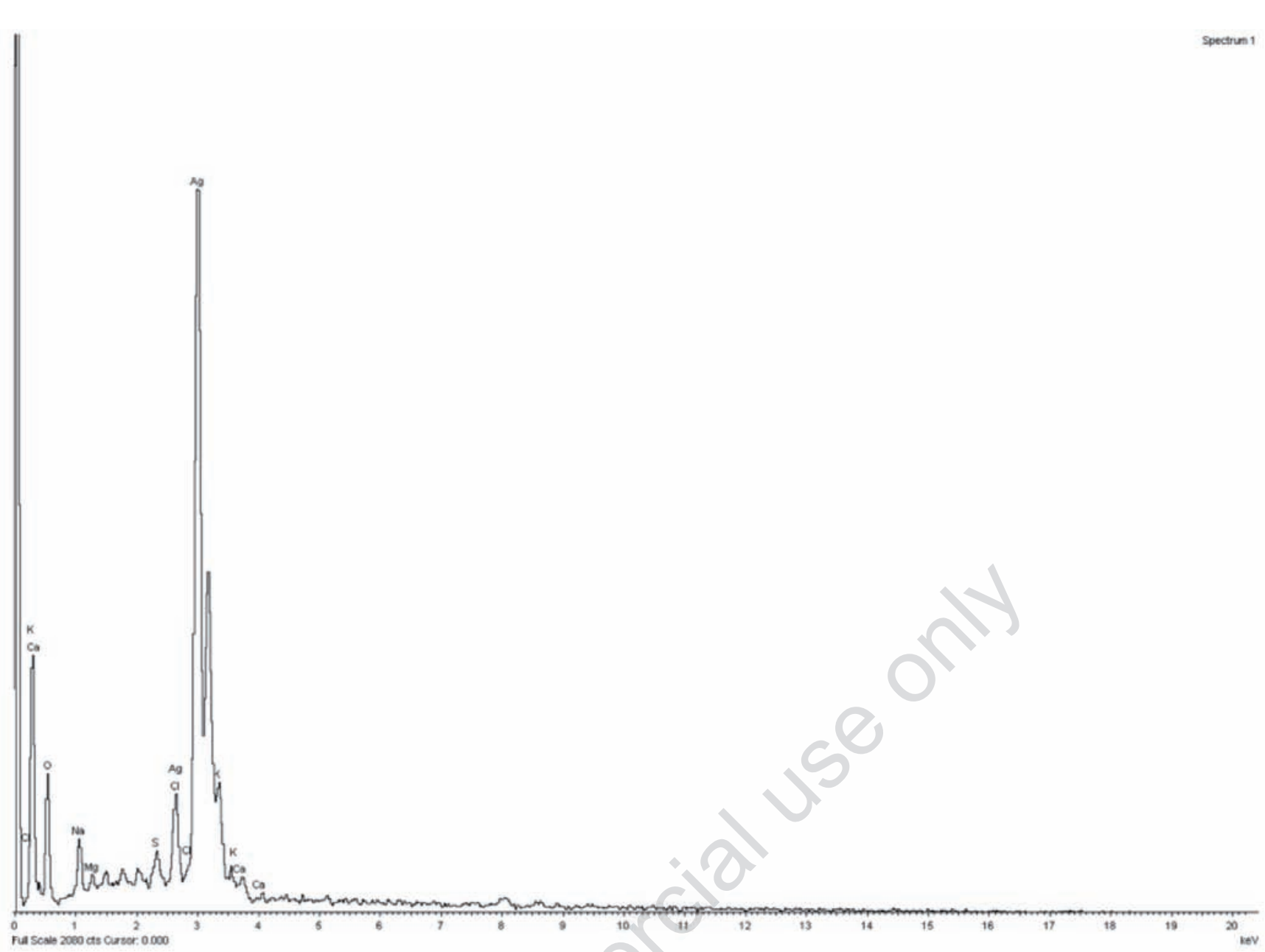

Figure 6. Energy dispersive X-ray spectra recorded form a film, after formation of silver nanoparticles with different X-ray emission peaks labeled. $\mathrm{Cl}$, chloro; $\mathrm{K}$, potassium; $\mathrm{Ca}$, calcium; $\mathrm{O}$, oxygen; $\mathrm{Na}$, sodium; $\mathrm{Mg}$, magnesium; $\mathrm{S}$, sulphur; $\mathrm{Ag}$, silver.

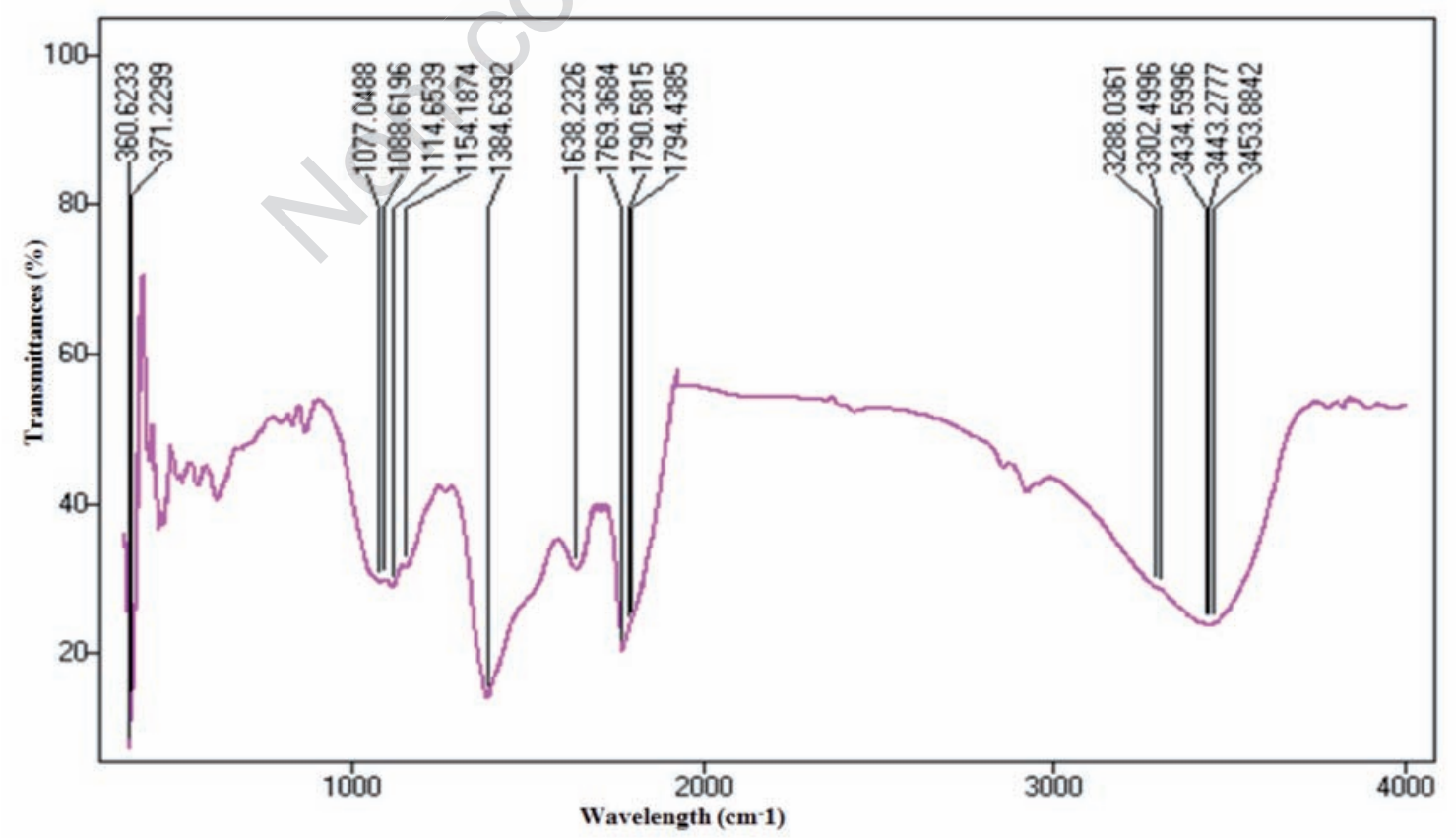

Figure 7. Fourier transformed infrared spectroscopy spectrum of silver nanoparticle synthesized by reacting silver nitrate with $C$. indica lam leaf extract. 
quinquefasciatus. The AgNPs formed are highly stable and significant mosquito larvicides. The synthesized AgNPs in a methanol extract and the isolation and purification of crude methanol extracts of $C$. indica lam are in progress. We also seek to develop methods and techniques necessary for green synthesis of silver nanoparticles by using microorganisms, such as bacteria and fungi, for mosquito control.

\section{References}

ABBOTT W.S., 1925 - A method of computing the effectiveness of insecticides. - J. Econ. Entomol. 18: 265-267.

AHMAD A., MUKHERJEE P., SENAPATI S., MANDAL D., KHAN M.I., KUMAR R., et al., 2003 - Extracellular biosynthesis of silver nanoparticles using the fungus Fusarium oxysporum. - Colloids. Surf. B. 28: 313-318.

ALAGESABOOPATHI C., 2009 - Ethnomedicinal plants and their utilization by villagers in Kumaragiri Hills of Salem District of Tamilnadu, India. - Afr. J. Tradit. Complement. Altern. Med. 6: 222-227.

BALAJI D.S., BASAVARAJA S., DESHPANDE R., MAHESH D.B., PRABHAKAR B.K., VENKATRAMAN A., 2009 - Extracellular biosynthesis of functionalized silver nanoparticles by strains of Cladosporium cladosporioides fungus. - Colloides. Surf. B. Biointerf. 68: 88-92.

BEGUM N.A., MONDAL S., BASU S., LASKAR R.A., MANDAL D., 2009 Biogenic synthesis of Au and Ag nanoparticles using aqueous solutions of Black Tea leaf extracts. - Colloids. Surf. B. Biointerf. 71: 113-118.

BOWERS W.S., 1992 - Biorational approaches for insect control. Korean. J. Appl. Entomol. 31: 289-303.

CHANDRAN S.P., CHAUDHARY M., PASRICHA R., AHMAD A., SASTRY M., 2006 - Synthesis of gold nanotriangles and silver nanoparticles using Aloe vera plant extract. - Biotechnol. Prog. 22: 577-583.

DURÁN N., MARCATO P.D., ALVES O.L., SOUZA G.I., ESPOSITO E., 2005 - Mechanistic aspects of biosynthesis of silver nanoparticles by several Fusarium oxysporum strains. - J. Nanobiotechnol. 13: 3-8.

EZEONU F.C., CHIDUME G.I., UDEDI SC., 2001- Insecticidal properties of volatile extracts of orange peels. - Bioresource. Technol. 76: 273.

FINNEY D.J., 1971 - Probit analysis. - Cambridge University, London: 68-78.

GHOSH S., SHARMA A.K., KUMAR S., TIWARI S.S., RASTOGI S., SRIVASTAVA S., et al., 2011 - In vitro and in vivo efficacy of Acorus calamus extract against Rhipicephalus (Boophilus) microplus. Parasitol. Res. 108: 361-70.

GOODSELL D.S., 2004 - Bionanotechnology: lessons from nature. Wiley, Hoboken: 1-52.

GOVINDARAJAN M., JEBANESAN A., PUSHPANATHAN T., 2008 Larvicidal and ovicidal activity of Cassia fistula Linn. leaf extract against filarial and malarial vector mosquitoes. - Parasitol. Res. 102: 289-292.

KOVENDAN K., MURUGAN K., 2011 - Effect of medicinal plants on the mosquito vectors from the different agro-climatic regions of Tamil Nadu, India. - Adv. Environ. Biol. 5: 335-344.

KOVENDAN K., MURUGAN K., PRASANNA KUMAR K., PANNEERSELVAM C., MAHESH KUMAR P., AMERASAN D., et al., 2012 Mosquitocidal properties of Calotropis gigantea (Family: Asclepiadaceae) leaf extract and bacterial insecticide, Bacillus thuringiensis, against the mosquito vectors. - Parasitol Res. 111: 531-544.

KRISHNARAJ C., JAGAN E.G., RAJASEKAR S., SELVAKUMAR P., KALAICHELVAN P.T., MOHAN N., 2010 - Synthesis of silver nanoparticles using Acalypha indica leaf extracts and its antibacterial activity against water borne pathogens. - Colloids. Surf. B. Biointerf. 76: 50-56.
MARIMUTHU S., RAHUMAN A.A., RAJAKUMAR G., SANTHOSHKUMAR T., VISHNU KIRTHI A., JAYASEELAN C., et al., 2011 - Evaluation of green synthesized silver nanoparticles against parasites. Parasitol. Res. 108: 1541-1549.

MOHANPURIA P., RANA N.K., YADAV S.K., 2008 - Biosynthesis of nanoparticles: technological concepts and future applications. - J. Nanopart. Res. 10: 507-517.

MORONES J.R., ELECHIGERRA J.I., 2005 - Interaction of silver nanoparticles with HIV-1. - Nanotechnol. 16: 2346.

MUKHERJEE P., ROY M., MANDAL B.P., DEY G.K., MUKHERJEE P.K., GHATAK J., et al., 2008 - Green synthesis of highly stabilized nanocrystalline silver particles by a non-pathogenic and agriculturally important fungus T. asperellum. - Nanotechnol. 19: 075103.

MULVANEY P., 1996 - Surface plasmon spectroscopy of nanosized metal particles. - Langmuir 12: 788-800.

PATHAK N., MITTAL P.K., SINGH O.P., VIDYA S., VASUDEVAN P., 2000 Larvicidal action of essential oils from plants against the vector mosquitoes Anopheles stephensi (Liston) Culex quinquefasciatus (Say) and Aedes aegypti (L). - Int. Pest. Cont. 42: 53.

PEACH K., TRACY M.V., 1955 - Modern methods of plant analysis, Vol. 3. - Springer. Verlag. 1-59.

RAJESH W.R., NIRANJAN S.K., JAYA R.L., VIJAY D.M., SAHEBRA0 B.K., 2010 - Extracellular synthesis of silver nanoparticles using dried leaves of pongamia pinnata (L) pierre. - Nano-Micro. Lett. 2: 106-113.

RASTOGI R.P., MEHROTRA B.N., 1991 - Compendium of Indian medicinal plants. Vol. II. - Central Drug Research Institute, New Delhi: pp 833.

REDDY K.N., PATTANAIK C., REDDY C.S., RAJU V.S., 2007 - Traditional knowledge on wild food plants in Andhra Pradesh, India, Indian. J. Traditional Knowledge. 6: 223-229.

SANTHOSHKUMAR T., RAHUMAN A.A., RAJAKUMAR G., MARIMUTHU S., BAGAVAN A., JAYASEELAN C., et al., 2011 - Synthesis of silver nanoparticles using Nelumbo nucifera leaf extract and its larvicidal active against malaria and filariasis vectors. - Parasitol. Res. 108: 693-702.

SAP-IAM N., HOMKLINCHAN C., LARPUDOMLERT R., WARISNOICHAROEN W., SEREEMASPUN A., DUBAS S.T., 2010 - UV irradiation induced silver nanoparticles as mosquito larvicides. - J. Appl. Sci. 10: 3132-3136.

SATHISHKUMAR M., SNEHA K., WON S.W., CHO C.W., KIM S., YUN Y.S., 2009 - Cinnamon zeylanicum bark extract and powder mediated green synthesis of nano-crystalline silver particles and its bactericidal activity. - Colloids. Surf. B. Biointerf. 73: 332-338.

SELVAMANI P., LATHA S., 2005 - Studies on thej m antimicrobial activity of cadaba indic lam. - Indian. J. Pharmaceut. Sci. 67: 637-638.

SINHA S., PAN I., CHANDRA P., SUKANTA K., SEN., 2009 Nanoparticles fabrication using ambient biological resource. Appl. Sci. 9: 1113-1130.

SONG J.Y., KIM B.S., 2008 - Biological synthesis of bimetallic Au/Ag Nanoparticle using persimmon (Diopyros kaki) leaf extract, Korean. - J. Chem. Eng. 25: 808-811.

STUART B.H., 2002 - Polymer analysis. - John Wiley \& Sons, London.

SUMODAN P.K., 2003 - Potential of rubber plantations as breeding source of Aedes albopictus in Kerala, India. - Dengue Bull. 27: 206-7.

THIRUNAVUKKARASU S., RAHUMAN A.A., GOVINDASAMY R., MARIMUTHU S., ASOKAN B., CHIDAMBARAM J., et al., 2010 Synthesis of silver nanoparticles using Nelumbo nucifera leaf extract and its larvicidal activity against malaria and filariasis vectors. - Parasitol. Res. 108: 693-702.

TIAN N., LIU Z., HUANG J., LUO G., LIU S., LIU X., 2007 - Isolation and preparation of flavonoids from the leaves of Nelumbo nucifera Gaertn by preparative reversed-phase high-performance liquid chromatography. Sepu. 25: 88-92.

TRIPATHI A., CHANDRASEKARAN N., RAICHUR A.M., MUKHERJEE A., 
2009 - Antibacterial applications of silver nanoparticles synthesized by aqueous extract of Azadirachta indica (Neem) leaves. - J. Biomed. Nanotechnol. 5: 93-98.

VIVEKANANDHAN S., MISRA M., MOHANTY A.K., 2009 - Biological synthesis of silver nanoparticles using Glycine max (soybean) leaf extract: an investigation on different soybean varieties. - J. Nanosci. Nanotechnol. 9: 6828-6833.
WHO, 2002 - Lymphatic filariasis-the disease and its control. Technical report no. 71. World Health Organization, Geneva.

WHO/UNICEF, NNDP/World Bank/WHO/TDR., 1997 - Research on rapid geographical assessment of Bancroftian filariasis. World Health Organization, Geneva.

WHO, 2007- Global plan to combat neglected tropical diseases 2008-2015. WHO/CDS/NTD/2007.40. World Health Organization, Geneva. 